\title{
РАЗВИТИЕ КОМПЕТЕНЦИЙ РАБОТНИКОВ-ИННОВАТОРОВ С ИСПОЛЬЗОВАНИЕМ ИНСТРУМЕНТОВ ГЕЙМИФИКАЦИИ
}

\author{
Е. Г. Калабина, А. С. Берестовой
}

\section{Уральский государственный экономический университет}

Поступила в редакцию 2 декабря 2019 г.

\begin{abstract}
Аннотация: исследуется применение геймификации как инструмента профессионального развития компетенций работников-инноваторов на основе внедрения игровых техник в неигровую среду корпораций. Дано авторское определение понятия компетенции работника-инноватора на основе компетентностного подхода, учитывающее как профессиональные знания, умения и навыки (hard skills), так и его личностно-деловые качества, так называемые «мягкие» компетенции (soft skills). Cучетом анализа позитивных и негативных факторов среды компаний установлены ключевые компетенции, характерные для работников-инноваторов, а такюе определены отличительные личностно-деловые качества как элемент компетенций работников-инноваторов. Описана взаимосвязь между компетенциями работника-инноватора, его личностно-деловыми качествами и этапами инноващионного процесса на основе профессиональных образовательных стандартов. Обосновано применение геймификации как инструмента профессионального развития компетенций работников-инноваторов и разработан алгоритм использования различных игровых техник для развития отдельных ключевых компетенций работников-инноваторов с учётом группового и индивидуального уровней, включая командную игровую технику по решению кейсов, решение изобретательских задач, деловые и ролевые игры исследовательской направленности.
\end{abstract}

Ключевые слова: геймификация, игровые техники, компетенции, работник-инноватор.

\begin{abstract}
: the article is devoted to the study of the use of gamification as a tool for the professional development of the competences of innovative workers based on the introduction of gaming techniques into the non-gaming environment of corporations. The author's definition of the concept "competence of an employee-innovator»" based on the competence-based approach, taking into account both professional knowledge and skills (hard skills) and his personal and business qualities, so-called soft skills, is given. The authors, taking into account the analysis of positive and negative factors of the environment of companies, have established key competencies characteristic of innovative workers, as well as identified distinctive personal and business qualities as an element of the competences of innovative workers. The relationship between the competences of the employee-innovator, his personal and business qualities and the stages of the innovation process based on professional educational standards is described. The use of gamification as a tool for the professional development of the competences of innovative workers has been substantiated and an algorithm has been developed for using various gaming techniques to develop individual key competencies of innovative workers taking into account group and individual levels, including team gaming equipment for solving case studies, solving inventive problems, business and role playing research directionality.
\end{abstract}

Key words: gamification, gaming techniques, competencies, employee-innovator.

Каждому этапу инновационного процесса свойственны свои закономерности и отличия. Так, достаточно сложно представить себе человека, который, занимаясь инновационным творческим трудом, рождая в своем воображении оригинальные идеи и нестандартные управленческие и/или инженерные решения, в то же время с интересом воспринимает творения других. Формы инновационной активности отдельного работника в компании, в рамках которых процессы рождения, восприятия, совершенствования и реализации различ-

(C) Калабина Е. Г., Берестовой А. С., 2020 ных инноваций протекают как на индивидуальном, так и групповом уровнях параллельно внутри одной и той же системы профессионального обучения и развития. Динамичное профессиональное обучение и развитие работников являются актуальными в современной быстроразвивающейся экономике, где непрерывное внедрение новшеств в производство и обслуживание требует от работников наличие соответствующих компетенций - знаний, опыта, умений, навыков. Это порождает вполне закономерный вопрос о том, как развивать и стимулировать развитие ключевых компетенций работников в условиях инновационной экономики? 
Особенно остро данный вопрос стоит в отношении тех работников, деятельность которых связана с генерированием, разработкой и созданием инноваций, ибо только за счет передовых знаний, навыков и мышления можно создавать новшества. В связи с этим данное исследование посвящено изучению инструментов для развития ключевых компетенции работников-инноваторов с использованием современного инструментария, стимулирующего творческие процессы, - геймификации.

В научной литературе последних десятилетий проблемам профессионального обучения и развития работников в компаниях посвящено много исследований, однако управленческая практика показывает, что вопросы формирования и развития компетенций работников-инноваторов являются не вполне изученной и раскрытой темой. Кроме того, если владеть современным инструментарием стимулирования инновационного труда, то, оценив профессиональную пригодность работника, можно создать благоприятную среду для инновационной деятельности внутри компаний - разработки нестандартных решений и оригинальных идей [1].

Целью исследования является изучение возможностей применения игровых техник - геймификации - для развития и управления компетенциями работника-инноватора в организации. Для достижения поставленной цели в работе решаются следующие задачи:

- определение специфики и возможностей применения геймификации как инструмента развития компетенций работников;

- уточнение и характеристика ключевых компетенций для работника-инноватора;

- разработка алгоритма развития ключевых компетенций работника-инноватора с применением инструментов геймификации.

На протяжении последних лет в научной литературе появились принципиально новые инструменты для профессионального развития, обучения и стимулирования трудовой деятельности работников. Одним из них является геймификация как применение элементов игры в неигровом контексте. Известны несколько определений категории «геймификация». Геймификация - это «внедрение игровых механик, аналогичных имеющимся в компьютерных играх, в текущие рабочие процессы в целом, в том числе в разработку механизмов эффективного благодарения персонала за качественно выполненную работу» [2] или «частичное включение игровых элементов, создание интерактивной системы взаимодействия без полноценной игры в качестве конечного продукта» или «целенаправленное использование игровых элементов для формирования нового опыта в неигровых задачах, процессах и контексте» [3].

При рассмотрении сущности геймификации исследователи едины в том, что она не является процессом создания игры, а выступает лишь переносом отдельных позитивных элементов и характеристик игры (цель, правила, обратная связь и свобода участия) в неигровую сферу.

Спецификой геймификации выступает направленность на вовлечение работников, превращение их в игроков, к потребностям которых система и апеллирует в первую очередь, а не на управление поведением через удовлетворение потребностей и стимулирование работника [4].

Наиболее эффективна геймификация, если она использует такие критерии, как чувство коллективизма; добровольность участия в игре, так как если игровая система контролирует все действия работников, то в результате работники не получают никакого удовольствия, а, наоборот, снижается внутренняя мотивация; прозрачность игрофицированной системы для понимания работниками целей и правил игры; наличие легенды, интригующей истории, вызывающей интерес и указывающей путь к достижению цели, помогает модифицировать задачи игрока, стабильно удерживать его внимание [5].

Получение удовольствия является одним из самых сильных мотиваторов, побуждающих человека увлеченно и с полной отдачей заниматься чем-либо. Поэтому, добавляя соревновательности и азарта в рабочий процесс, используя механизмы игры, игровые элементы и формируя игровое мышление, можно добиться вовлеченности работников, энтузиазма в выполнении работы, а также создать обучающую среду организации, формирующую новый профессиональный опыт и способы решения проблем, поле возможностей для экспериментирования, поскольку только в игре, не опасаясь за возможность провала, всегда можно начать заново [4].

Во время игры человек на некоторое время отстраняется от личных потребностей - их замещают игровые цели, достижение которых в данном игровом контексте является внутренне мотивированным желанием игрока. Следовательно, базовая особенность геймификации состоит в том, что она создает контекст для деятельности, который способен поощрять и мотивировать сам по себе, в то время как большинство традиционных систем мотивации лишь использует внешние стимулы [там же]. 
В результате геймификация выступает инструментом стимулирования, профессионального обучения и развития работников, основывающемся на внедрении игровых техник и психологии игры в неигровую среду компаний, которые способствуют формированию игрового мышления, чувства коллективизма, повышению трудовой мотивации, вовлеченности работников и отдачи в их деятельности. Геймификация позволяет заинтересовать работника в творческом поиске путём снижения рутины и повышения его вовлеченности и заинтересованности в обучающем процессе, дать опыт взаимодействия с другими работниками, коллективной работы, формирования идей как в групповой, так и в индивидуальной форме, мотивировать к саморазвитию и превосходству, чтобы быть лучшим среди других работников.

Игровая среда создаёт благоприятную комфортную атмосферу и раскрепощает работника, даёт ему возможность проявлять креативность, предлагать идеи, совершать действия, которые он бы не стал делать в обычной рабочей среде из-за возможности неприятия этих идей как со стороны руко- водства, так и со стороны коллег, бюрократизации и других негативных факторов. Однако, чтобы организовать благоприятную среду, необходимо выявить, какие ключевые компетенции работника следует развивать (навыки, знания, умения) и как стимулировать их развитие у работника.

На современном этапе развития экономики наиболее перспективен компетентностный подход к управлению и стимулированию развития ключевых компетенций работников в компаниях. Компетентностный подход в управлении сформировался учеными по всему миру за сравнительно длительный период времени, но именно сейчас на него стал делаться больший упор в научной среде.

Компетентностный подход в управлении состоит в соединении ключевых компетенций организации и индивидуальных компетенций работников. Основой компетентностного подхода является понятие «компетенция». Рассмотрим основные подходы к его трактовке (табл. 1).

Данные концептуальные подходы характеризуют различные аспекты понятия «компетенция». Таким образом, можно определить понятие «ком-

Т а б ли ц а 1

Базовые теоретические подходы к трактовке понятия «компетенция»

\begin{tabular}{|c|c|c|}
\hline Концептуальный подход & Содержание & Авторы \\
\hline Личностно-деловой & $\begin{array}{l}\text { Деловые и личностные качества, присущие каждому сотруднику } \\
\text { корпорации вне зависимости от занимаемой должности и содер- } \\
\text { жания деятельности, отражающие ценности компании, во многом } \\
\text { определяют корпоративную культуру организации. Каждая ком- } \\
\text { петенция представляет собой сочетание профессиональных зна- } \\
\text { ний, навыков, умений, установок, ориентаций, индивидуальных } \\
\text { качеств человека [6, с. 374] }\end{array}$ & А. С. Боровец \\
\hline Эффективный & $\begin{array}{l}\text { Комбинация знаний, умений, навыков, мотивационных факторов, } \\
\text { личностных качеств и ситуационных намерений, которая обеспе- } \\
\text { чивает эффективное решение исполнителем задач определенного } \\
\text { класса в определенной организации, на определенном рабочем ме- } \\
\text { сте, в определенном производственном коллективе [7, с. 99] }\end{array}$ & $\begin{array}{l}\text { Т. Ю. Базаров, } \\
\text { А. К. Ерофеев, } \\
\text { А. Г Шмелев }\end{array}$ \\
\hline Ситуационный & $\begin{array}{l}\text { Личные качества, способности и профессиональные навыки че- } \\
\text { ловека, необходимые ему для устройства на работу и выполнения } \\
\text { своих должностных обязанностей. Поэтому для каждого работни- } \\
\text { ка в определенной рабочей сфере образовываются свои компетен- } \\
\text { ции, присущие сложившейся ситуации }[8, \text { с. } 140]\end{array}$ & Ю. М. Галашкина \\
\hline Личностный & $\begin{array}{l}\text { Понимание ее как свойства личности, потенциальной способно- } \\
\text { сти индивида справляться с различными задачами, как совокуп- } \\
\text { ности знаний, умений и навыков, необходимых для осуществле- } \\
\text { ния конкретной профессиональной деятельности [9, с. 190] }\end{array}$ & М. В. Кондурар \\
\hline Предметный & $\begin{array}{l}\text { Предметная область, в которой индивид хорошо осведомлен и } \\
\text { проявляет готовность к выполнению деятельности [10, с. 97] }\end{array}$ & М. А. Лукашенко \\
\hline Трудовой & $\begin{array}{l}\text { Способность применять знания, умения, отношения и опыт в зна- } \\
\text { комых и незнакомых трудовых ситуациях }[11, \text { с. } 35]\end{array}$ & $\begin{array}{l}\text { А. Э. Федоров, } \\
\text { С. Е. Метелев, } \\
\text { А. А. Соловьев, } \\
\text { Е. В. Шлякова }\end{array}$ \\
\hline
\end{tabular}


петенция〉 работника как совокупность профессиональных знаний, навыков, умений, установок, ценностей, усилий, поведенческих моделей, ориентаций, индивидуальных деловых и личностных качеств работника, обеспечивающих эффективное достижение целей корпорации.

Компетентностный подход как инструмент управления профессиональным развитием работников дает четкие профессиональные и поведенческие требования к работникам корпорации, отражающие уровень должности, профессию и особенности выполняемых задач.

Управление компетенциями работника - «совокупность действий, направленных на приобретение необходимой компетенции в соответствии с потребностями корпорации, которые определяются путем сравнения ее потребностей с имеющимися ресурсами» [12]. Управление компетенцией на уровне работника состоит в оценке своих возможностей в соответствии с критериями по исполняемой работе, а если компетенции не полностью соответствуют критериям, то проводится обучение работника.

Знания, полученные работниками в учебных заведениях, требуют постоянного обновления. Поэтому все большее развитие получает идея создания систем непрерывного развития работников. Компетентностный подход акцентирует внимание на способности использовать полученные знания. С позиций компетентностного подхода основным результатом деятельности становится формирование ключевых компетенций. Компетентностный подход делает акцент на получение опыта самостоятельного решения проблем, и этот опыт нужен не как некое приложение к полученным знаниям, а как основа всего процесса [5].

Каждая профессиональная категория работников в компании обладает своей неповторимой спецификой, которую необходимо учитывать при формировании и развитии компетенций. Работники-инноваторы «активно участвуют в инновационном процессе, генерируют или воплощают инновационные идеи, готовы идти на определенный риск при разработке и воплощении идей, но при этом их действия представляют собой симбиоз разработки новшества, его организационное внедрение и коммерциализацию» [13]. По нашему мнению, такими работниками в корпорациях являются те работники, которые отвечают за разработку инновационных идей и их дальнейшее воплощение, прежде всего инженерно-технический персонал (программисты, разработчики инноваци- онных продуктов, инженеры-технологи и инженеры-конструкторы), в функционал которых входит создание, разработка и внедрение инновационных продуктов.

Следует отметить, что специфика труда работника-инноватора заключается в интеллектуальности и наличии элементов творчества. Но интеллектуальный труд непросто оценивать, что затрудняет процесс его измерения, соответственно, становится трудно найти инструменты стимулирования деятельности работника-инноватора. Мы считаем, что необходимо рассматривать опыт, склонность, способности и навыки работника-инноватора, а для этого следует обратиться к тому набору ключевых компетенций, которыми должен обладать работник-инноватор.

Теоретический и эмпирический анализ позволили нам выявить ключевые компетенции, присущие работнику-инноватору (табл. 2).

Результаты проведенных исследований свидетельствуют о том, что большая часть ключевых компетенций работника-инноватора рассматривается как «мягкие» компетенции (soft skills) - личностно-деловые качества, отражающие необходимый стандарт коммуникативного и трудового поведения, упуская из характеристики конкретные профессиональные навыки и знания работника-инноватора. Основываясь на проведенных исследованиях, мы предложили дополнить следующие личностно-деловые качества как элемент инновационных компетенций: креативность (способность предлагать и разрабатывать инновационные идеи), обучаемость (способность и склонность к обучению и развитию в необходимой области исследований), предприимчивость (готовность к активному участию в инновационном процессе), сотрудничество (умение работать в коллективе), восприимчивость к инновациям (способность оценивать инновационный потенциал), системность мышления (способность критически оценивать, анализировать, делать выводы), лидерство (способность организовывать развитие инновационной инициативы).

Исходя из определений понятия «компетенция», мы предлагаем следующую схему способов формирования ключевых компетенций работников-инноваторов в корпорации. По нашему мнению, компетенции работника-инноватора зависят от совокупности компетенций, полученных как вне корпорации (образование, самообразование и опыт работника в других корпорациях), так и внутри нее (внутрикорпоративное обучение и 
Ключевые компетенции работника-инноватора [14-19]

\begin{tabular}{|c|c|}
\hline Компетенция работника-инноватора & Характеристика компетенции \\
\hline $\begin{array}{l}\text { Быть способным к выявлению проблем } \\
\text { и методов их решения }\end{array}$ & $\begin{array}{l}\text { Наличие актуального проблемного поля и его потенциального реше- } \\
\text { ния является основой создания инновационной идеи. Определение } \\
\text { потребности корпорации и её клиентов в определенном продукте и } \\
\text { последующее её удовлетворение позволят прийти как к разработке } \\
\text { конкретной инновации, так и к успешной её реализации }\end{array}$ \\
\hline $\begin{array}{l}\text { Обладать творческой } \\
\text { самостоятельностью }\end{array}$ & $\begin{array}{l}\text { Наличие данной компетенции позволяет работнику-инноватору } \\
\text { самостоятельно придумывать и разрабатывать потенциальную } \\
\text { инновационную идею до финальной стадии в виде внедренной } \\
\text { инновации }\end{array}$ \\
\hline Обладать критическим мышлением & $\begin{array}{l}\text { Критическое мышление позволяет работнику-инноватору отбрасы- } \\
\text { вать ненужные идеи и находить всевозможные факторы, которые } \\
\text { влияют на успешность инновации }\end{array}$ \\
\hline $\begin{array}{l}\text { Быть способным и готовым к } \\
\text { непрерывному образованию, } \\
\text { самообучению и обучению других }\end{array}$ & $\begin{array}{l}\text { Наличие передовых знаний и навыков даёт больше пространства } \\
\text { для инновационной деятельности, поскольку работник, обладаю- } \\
\text { щий такими знаниями, может шире и глубже понимать исследуе- } \\
\text { мую проблематику, он в курсе современных научных разработок } \\
\text { и может усовершенствовать имеющиеся технологии производства } \\
\text { конкретного продукта }\end{array}$ \\
\hline Быть способным работать в команде & $\begin{array}{l}\text { Командная работа способствует обмену инновационными идеями, } \\
\text { их совершенствованию, а также взаимной передаче знаний и опыта } \\
\text { между работниками }\end{array}$ \\
\hline $\begin{array}{l}\text { Участвовать в разработке и реализации } \\
\text { инновационных проектов }\end{array}$ & $\begin{array}{l}\text { Работник-инноватор не должен быть инертным, именно постоян- } \\
\text { ное участие в создании инновации способствует повышению его } \\
\text { знаний, опыта, что будет позитивно влиять на его «профессио- } \\
\text { нальную интуицию» и способствовать более качественной генера- } \\
\text { ции инноваций }\end{array}$ \\
\hline $\begin{array}{l}\text { Уметь прогнозировать результаты своих } \\
\text { нововведений }\end{array}$ & $\begin{array}{l}\text { Работник-инноватор должен уметь предвидеть потенциальный ре- } \\
\text { зультат разрабатываемой инновации для эффективности своей дея- } \\
\text { тельности }\end{array}$ \\
\hline $\begin{array}{l}\text { Уметь быть организатором, быть } \\
\text { инициативным }\end{array}$ & $\begin{array}{l}\text { Работник-инноватор не должен бояться брать на себя ответствен- } \\
\text { ность за возможность создания инновации. Благодаря инициатив- } \\
\text { ности работник-инноватор активизирует инновационный процесс } \\
\text { в корпорации }\end{array}$ \\
\hline $\begin{array}{l}\text { Уметь предложить и обосновать прин- } \\
\text { ципиально отличающиеся от общих } \\
\text { норм идеи, направленные на изменение } \\
\text { ситуации }\end{array}$ & $\begin{array}{l}\text { Чаще всего инновации имеют революционный характер, радикаль- } \\
\text { но меняющий имеющийся технологический процесс, работник-ин- } \\
\text { новатор должен уметь отстаивать свою идею, так как идея, идущая } \\
\text { вразрез с имеющимися нормами, может нести в себе громадный } \\
\text { потенциал и принести успех корпорации }\end{array}$ \\
\hline
\end{tabular}

повышение квалификации работников-инноваторами, передача опыта между работниками-инноваторов корпорации, управление компетенциями работников-инноваторов и их развитие).

Чтобы развивать компетенции работника, необходимо знать, какие компетенции им были приобретены докорпорационно. Компетенции в виде знаний и навыков формируются на стадии получения образования будущего работника-инноватора. Инновационная деятельность в принципе характерна для многих работников, поэтому мы проанализировали образовательные стандарты по другим направлениям. Исходя из приведенных компетенций в различных образовательных стандартах нами были выделены основные компетенции в рамках этапов инновационного процесса. Мы рассмотрели трудовые функции в различных профессиональных стандартах, связанных с инновационной деятельностью, выделили основные трудовые функции в рамках этапов инновационного процесса. Проанализировав существующие личностно-деловые качества как элемент инновационных компетенций, существующие инновационные компетенции в образовательных стандартах и инновационные трудовые функции в рамках профессиональных стандартов, можно определить их взаимосвязь в рамках инновационного процесса (табл. 3). 


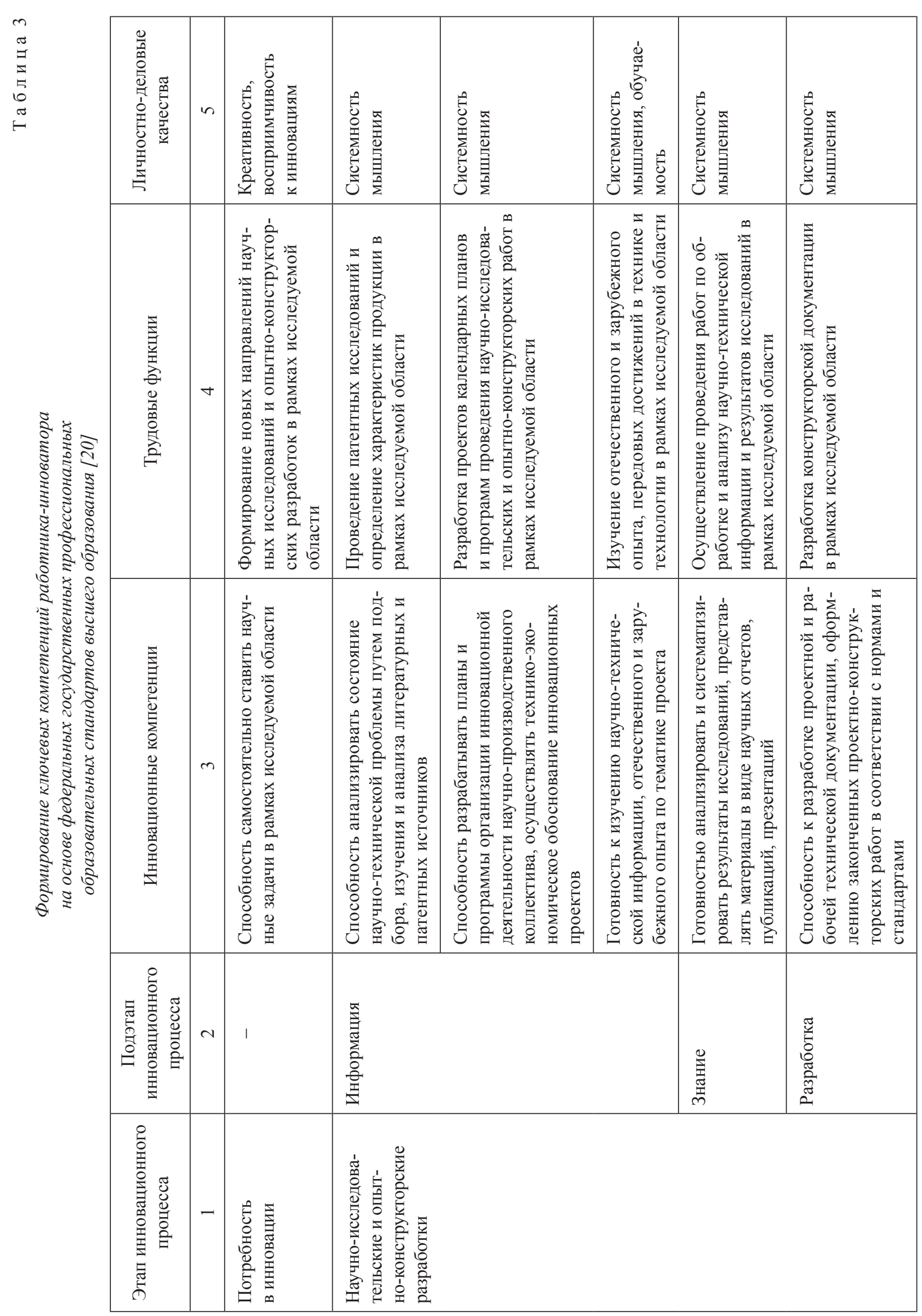




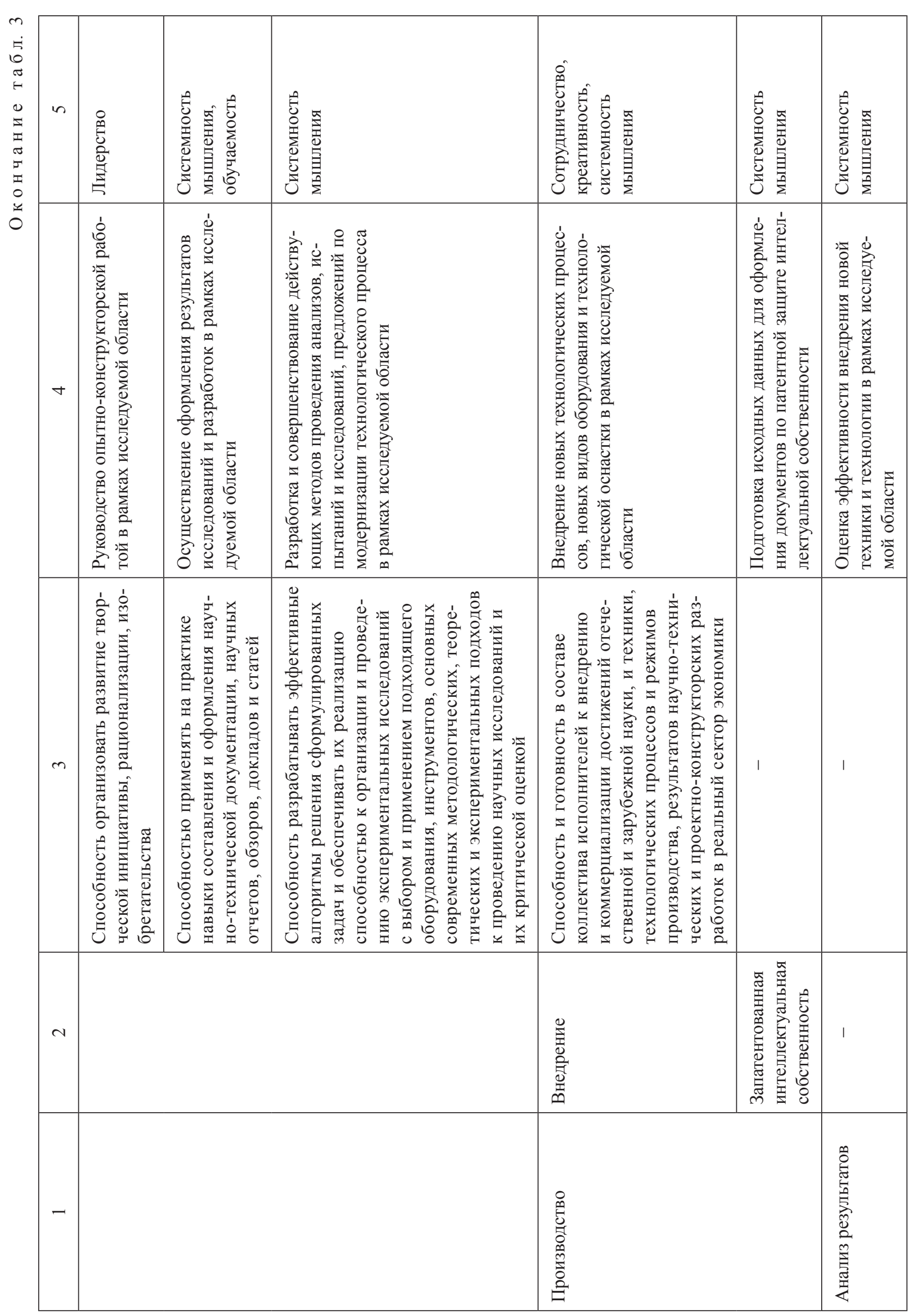


Для развития и стимулирования компетенций работника-инноватора необходимо учитывать непредсказуемость результатов и условность временных рамок его труда из-за сложности поставленной задачи. Поэтому кроме инновационного труда за результат требуется его оценка в рамках стадий инновационного процесса для контроля и стимулирования. Специфика инновационного труда ярко отображается в инновационном процессе, так как инновация является результатом интеллектуальной деятельности работника-инноватора на этапе научно-исследовательских и опытно-конструкторских разработок в виде полученных знаний, реализованных в разработанном новшестве, на этапе производства специфика проявляется в запатентованной интеллектуальной собственности.

Наиболее подходящим инструментом профессионального развития и обучения работников-инноваторов является геймификация, способствующая стимулированию и развитию навыков для инновационной деятельности. С помощью геймификации можно развивать компетенции таких этапов инновационного процесса, как потребность в инновации и научно-исследовательские и опытно-конструкторские разработки.

Выявив, что важными личностно-деловыми качествами работника-инноватора являются креативность, восприимчивость к инновациям, лидерство, системность мышления, сотрудничество, мы пришли выводу, что именно делая упор на развитие этих качеств, можно сформировать необходимые компетенции работника-инноватора.

Личностно-деловые качества развиваются и приобретаются как путём работы индивидуума над собой, так и за счет деятельности, позволяющей их стимулировать в результате совершения практических действий. Сложно научиться лидерству, сотрудничеству и т. д., не совершая конкретных действий для этого. Создать условия, которые могли бы позволить работнику-инноватору развивать и приобретать мягкие компетенции (soft skills), можно путем моделирования ситуации, где работники-инноваторы выполняют определенные задачи и совершенствуют, таким образом, себя.

Так как инноватор - работник творческий, креативный, создающий, в условиях его деятельности должны быть учтены факторы, которые влияют на эту деятельность как с позитивной, так и с негативной точки зрения, и именно за счет геймификации можно устранить данные проблемы и решить поставленные задачи. Работники-инноваторы восприимчивы к незначительному вовлечению в общий трудовой процесс, к отсутствию четких механизмов реализации инновации, мешающих им выполнять свою работу, к отсутствию понятных «правил» и т. п. [13]. Если устранить эти проблемные точки, то можно улучшить среду для трудовой деятельности работников-инноваторов. За счет введения игровых техник и/или игровых элементов можно развивать требуемые soft skills - личностно-деловые качества, необходимые для овладения требуемыми ключевыми компетенциями.

Развитие личностно-деловых качеств возможно только за счет каких-либо практических действий, а не теоретического изучения. Соответственно, необходима система развития, позволяющая усовершенствовать данные навыки. Поэтому для работников-инноваторов нужна система, которая учитывает их специфику.

Существует множество успешных примеров геймификации (например, Альфа-Банк использует симулятор «Альфа-город», для стимулирования продаж банковских продуктов с помощью специальных баллов, которые можно потратить на строительство зданий в игре либо обменять на подарки, а Департамент труда и пенсий Великобритании использует игровые техники для стимулирования инноваций свыше 120 тысяч сотрудников [21]), но конкретного алгоритма по её применению, а тем более развития компетенций работника-инноватора с её помощью в научной среде разработано не было.

Для развития ключевых компетенций работника-инноватора на основе управления его деловыми качествами мы предлагаем ввести геймифицированную систему, которая будет основываться на игровых техниках, позволяющих развивать лидерство, сотрудничество, передачу опыта внутри коллектива, совместное решение задач. Для этого подойдёт командная игровая техника по выполнению определенных кейсов: нескольким группам работников-инноваторов даются определенные командные задания по разработке инновационных идей, взаимодействуя между собой, работники-инноваторы разрабатывают инновационные идеи, таким образом, обучаясь сотрудничеству, передают свой опыт более молодым сотрудникам, отстаивают командную идею в дискуссии с другими командами, обучаясь лидерству. Более успешные команды работников-инноваторов должны поощряться за командные и индивидуальные достижения, которые будут их стимулировать к дальнейшему развитию. 
Геймификация может проводиться как в групповой, так и в индивидуальной форме, в зависимости от перечисленных ранее целей по развитию компетенций работника-инноватора. Среди игровых методов, используемых в геймификации, мы выделяем деловую игру исследовательской направленности в виде командного мозгового штурма для групповых форм развития с целью развить навыки групповой работы, передачи опыта между работниками-инноваторами и креативности, а также ролевую игру исследовательского типа, в ходе которой работники-инноваторы занимают определенную роль в команде для решения поставленных целей и задач. Также мы бы отметили аналогичные индивидуальные формы деловых и ролевых игр, которые позволяют работникам-инноваторам разрабатывать и отстаивать свои идеи, развивая таким образом лидерство и креативность.

Мы предлагаем алгоритм развития компетенций работника-инноватора с помощью применения инструментов геймификации (рисунок).

Формирование и развитие ключевых компетенций работника-инноватора может быть реализова- но с помощью определенного алгоритма действий. Используя данный алгоритм, выбирают, какие компетенции необходимо развивать, от этого будет зависеть и выбор типа развития. Групповой тип позволяет вовлекать работника-инноватора в рабочий процесс, способствует обучению и развитию работников путем обмена знаниями и опытом между работниками-инноваторами и командной работы. Данные действия позволяют развивать обучаемость (передача опыта от других работников-инноваторов), креативность (создание инновационной идеи) и лидерство (отстаивание идей в группе), а в индивидуальном типе - также обучаемость (передача опыта от других работников-инноваторов), креативность и восприимчивость к инновациям (создание полной концепции инновационной идеи) и развитие лидерства (отстаивание идей среди других работников-инноваторов).

Оба типа нацелены на развитие компетенций, принадлежащих таким этапам инновационного процесса, как «потребность в инновации» и «научно-исследовательские и опытно-конструкторские разработки», но упор на личностно-деловые

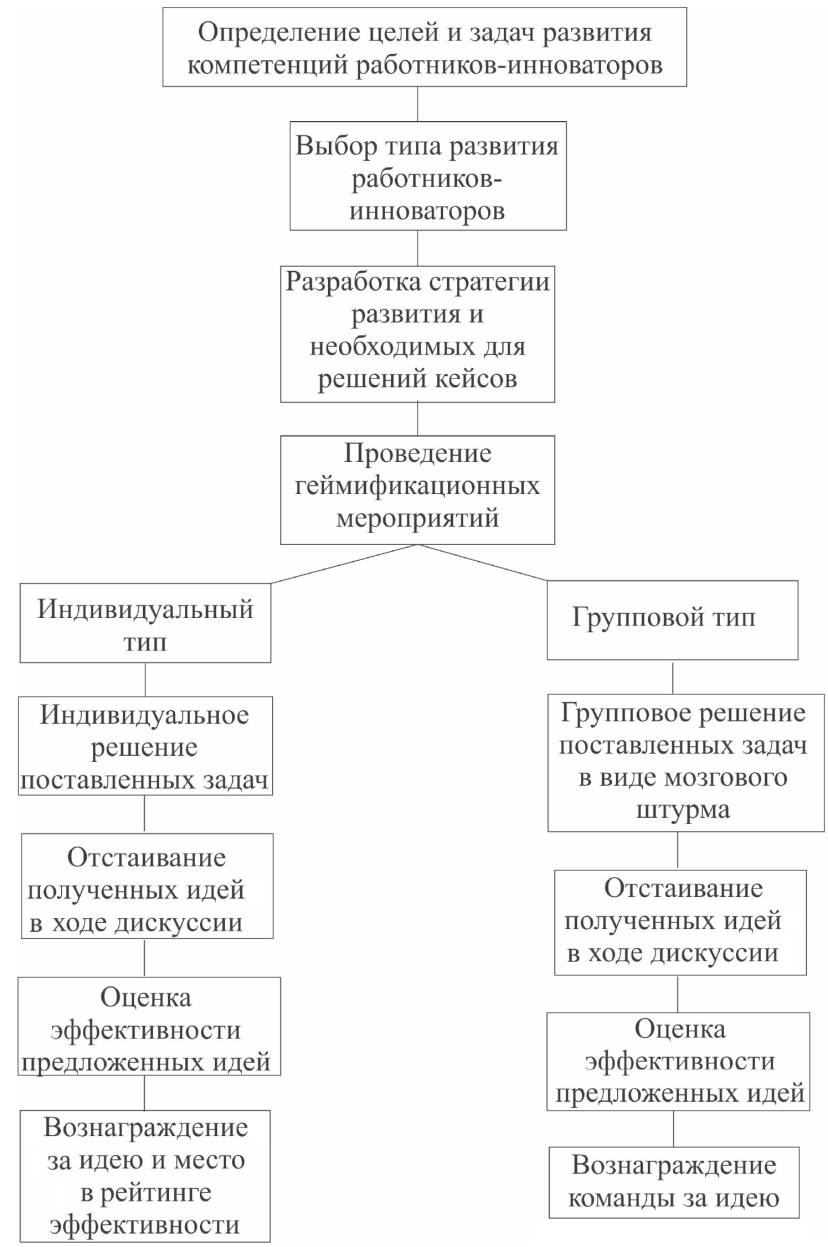

Рисунок. Алгоритм развития компетенций работников-инноваторов с помощью геймификации 
качества у каждого подхода разный. Если групповой этап - это прежде всего работа в команде, опыт взаимодействия с другими работниками-инноваторами и обмен знаниями, то индивидуальный тип - это больше индивидуальный поиск инновационной идеи вместе с её индивидуальным отстаиванием.

Несмотря на большое количество исследований по развитию компетенций, исследованная нами тема развития компетенций работников-инноваторов практически не была затронута.

В результате мы можем сделать следующие выводы.

1. Геймификация выступает инструментом стимулирования и развития работников с помощью внедрения игровых механик и психологии игры в неигровую среду корпорации с целью формирования игрового мышления, чувства коллективизма, повышения мотивации, вовлеченности работников и отдачи в их деятельности.

\section{ЛИТЕРАТУРА}

1. Калабина Е. Г. Эволюция системы отношений «работник - работодатель» в экономической организации / Е. Г. Калабина. - Екатеринбург : ИЭ УрО РАН, 2011. -437 с.

2. Курганова Е. Б. Игровые технологии в стимулировании персонала / Е. Б. Курганова // Вестник Воронежского государственного университета. Серия : Филология. Журналистика. - 2015. - № 2. - С. 123-124.

3. Маркеева A. B. Геймификация как инструмент управления персоналом современной организации / А. В. Маркеева // Российское предпринимательство. 2015. - Т. 16, № 12. - С. 1923-1936.

4. Ребров А. В. Геймификация и автоматизация КРI : очередная управленческая мода или новые методы стимулирования? / А. В. Ребров, А. Ю. Черкасов // Российский журнал менеджмента. - 2017. - Т. 15, № 3. C. 303-326.

5. Леонова О. В. Компетентностный подход как способ управления персоналом предприятия военно-промышленного комплекса / О. В. Леонова, О. В. Колосова // Вестник ТГТУ. - 2010. - Т. 16, № 4. C. 993-1000.

6. Боровеи А. С. Оценка и стимулирование компетенций персонала рекламного бизнеса / А. С. Боровец // Вестник Белгородского университета потребительской кооперации. - 2009. - № 3. - С. 373-379.

7. Базаров Т. Ю. Коллективное определение понятия «компетенции» : попытка извлечения смысловых тенденций из размытого экспертного знания / Т. Ю. Базаров, А. К. Ерофеев, А. Г. Шмелев // Вестник Московского университета. Серия 14 : Психология. - 2014. № 1. - С. 87-101.
2. Определив компетенции работников-инноваторов и личностно-деловые качества, связанные с ними, мы предложили геймификацию как инструмент развития компетенций работников-инноваторов и разработали алгоритм её применения. Развитие компетенций работников-инноваторов с помощью геймификации может осуществляться как групповым, так и индивидуальным путём, развивая соответствующие личностно-деловые качества работника-инноватора с целью развития его компетенций.

3. Групповая геймификация используется для обмена знаниями и опытом между работниками-инноваторами, развития навыков командной работы, развития обучаемости, креативности и лидерства.

4. Индивидуальная геймификация используется для поиска инновационной идеи и её индивидуального отстаивания, развития навыков обучаемости, креативности и восприимчивости к инновациям, а также лидерства.

8. Галашкина Ю. М. Теоретический аспект компетентности. Виды компетенции. Формирование компетенции как фактора конкурентоспособности работника / Ю. М. Галашкина // Вопросы экономики и управления. 2016. - № 5. - С. 138-142.

9. Кондурар M. В. Понятия компетенция и компетентность в образовании / М. В. Кондурар // Вектор науки ТГУ. - 2012. - № 1 (8). - С. 189-191.

10. Лукашенко А. М. Профессиональные компетенции руководителя / А. М. Лукашенко // Современная конкуренция. - 2009. - № 6. - С. 96-105.

11. Компетентностный подход в образовательном процессе : монография / А. Э. Федоров, С. Е. Метелев, А. А. Соловьев, Е. В. Шлякова.-Омск : Омскбланкиздат, 2012. - 210 c.

12. Гашкова Л. В. Теоретические основы формирования компетенции как формы современного менеджмента / Л. В. Гашкова // Инновационный транспорт. 2014. - № 3 (13). - С. 53-57.

13. Калабина Е. Г. Факторы инновационного поведения работника промышленного предприятия / Е. Г. Калабина, А. С. Берестовой // Вестник Челябинского государственного университета. Серия : Экономические науки. - 2017. - № 10 (406), вып. 58. - С. 139-146.

14. Глухих И. Н. Инновационная образовательная среда университета и компетенции выпускника-инноватора / И. Н. Глухих, Е. Н. Пряхина // Историческая и социально-образовательная мысль. - 2015. - Т. 7, № 4. C. 133-136.

15. Федоров О. Г. Современные подходы к развитию инновационной компетентности работников социальной сферы / О. Г. Федоров // Казанский педагогический журнал. - 2015. - № 5 (112). - С. 51-58. 
16. Anisha N. Competency Mapping of the Employees / N. Anisha // International Journal of Advancements in Research \& Technology. - 2012. - Vol. 1, iss. 5. - URL: http://www.ijoart.org/docs/Competency-Mapping-of-theEmployees.pdf

17. Kettunen $J$. Innovation pedagogy and desired learning outcomes in higher education / J. Kettunen, L. Kairisto-Mertanen, T. Penttilä // On the Horizon. - 2013.Vol. 21, iss. 4. - P. 333-342.

18. Эсаулова И. А. Инновационные компетенции как основа инновационного поведения сотрудников организации / И. А. Эсаулова, Н. В. Линькова, А. А. Меркушева // Вестник Университета (Государ-

Уральский государственный экономический университет

Калабина Е. Г., доктор экономических наук, профессор кафедры экономики предприятий

E-mail: kalabina@usue.ru

Берестовой А. С., аспирант кафедры экономики предприятий

E-mail: artyomber@yandex.ru ственный университет управления). - 2015. - № 5. C. 330-335.

19. Cerinšek G. 'Identifying employees' innovation competency in organisations' / G. Cerinšek, S. Dolinšek // Innovation and Learning. - 2009. - Vol. 6, № 2. - P. 164 177.

20. Федеральные государственные профессиональные образовательные стандарты высшего образования. URL: http://fgosvo.ru/docs

21. Маркеева A. B. Геймификация в бизнесе : проблемы использования и перспективы развития / А. В. Маркеева // Лидерство и менеджмент. - 2015. T. 2, № 3. - C. 169-190.

\section{Ural State University of Economics}

Kalabina E. G., Doctor of Economics, Professor of the Department «Enterprises Economics»

E-mail: kalabina@usue.ru

Berestovoy A. S., Post-graduate Student of the Department «Enterprises Economics»

E-mail: artyomber@yandex.ru 